\title{
RBM38 Gene
}

National Cancer Institute

\section{Source}

National Cancer Institute. RBM38 Gene. NCI Thesaurus. Code C99641.

This gene is involved in both RNA splicing and mRNA stability. 